\title{
Insulin-like growth factors and insulin: comparative aspects
}

\author{
E. R. Froesch and J.Zapf \\ Metabolic Unit, Department of Medicine University of Zürich, Zürich, Switzerland
}

\begin{abstract}
Summary. IGF I and IGF II are two insulin-like growth factors resembling insulin in many respects. They stem from a common precursor, act through receptors similar to the insulin receptor with which they cross-react. When administered in large amounts they produce hypoglycemia. Their major effects, however, are on replication and differentiation of cells of mesodermal origin. IGF I is the major growth promoting factor in vivo. The synthesis and secretion of IGF I by the liver
\end{abstract}

depend on the growth hormone status, insulin and nutrition. In contrast to insulin, the IGFs circulate in blood bound to the carrier proteins. Their half-life in man is in the order of $16 \mathrm{~h}$. IGF I deficiency results in dwarfism (pygmy, Laron dwarf, toy poodle) despite normal or elevated growth hormone secretion. The anabolic actions of insulin and of the IGFs appear to complement each other as shown in Figure 7.
Insulin was discovered in 1921 [1] and its structure elucidated in 1955 [2]. At about the same time, Salmon and Daughaday [3] made their first observation of an activity of serum that stimulates sulphate incorporation into cartilage. The structures of the two major insulin-like growth factors (IGF) I and II, which are responsible for this sulphation activity, were elucidated in 1978 [4, 5]. At present, comparison between insulin and insulin-like growth factors can be only tentative and incomplete since a great deal more is known about insulin than its relatives, the insulin-like growth factors. There are, however, many striking analogies as well as astounding differences between these two hormones, some of which will be discussed in detail.

The relationship between the somatomedins (SM) and insulin-like growth factors has been clarified. IGF I, SMC and SMA are identical [6, 7]. IGF II has no SM partner because it has not been purified by any of the groups using the SM nomenclature. The rat homologue of IGF II is MSA purified from conditioned medium of Buffalo rat liver cells.

\section{Structure and evolutionary aspects}

The most important steps leading to the discovery of non-suppressible insulin-like activity and thence to the identification of IGF I and II have been reviewed recently [8]. Insulin, IGF I and IGF II are members of a family of regulatory polypeptides which are characterized by a high degree of sequence homology [9]. In addition, the three polypeptides have several biological activities in common and crossreact with each others' receptors $[10,11]$. It has been shown recently that IGF I maps to chromosome $12[12,13]$ which is related to chromosome 11 and which also carries the gene for the proto-oncogene c-KI-ras-2 $[14,15]$. The genes for insulin and IGF II are located on the short arm of chromosome $11[12,13]$ which also contains the gene for the proto-oncogene c-HA-ras-1 [16]. The amino acid sequence and tertiary structure of insulin on the one hand and of the IGFs, on the other hand, exhibit considerable homology. The IGFs consist of an A-domain which resembles the A-chain of the insulin molecule and a B-domaine which is homologous to the insulin Bchain (Fig.1). These two domains are connected by a Cdomaine which consists of 12 amino acids in the case of IGF I and of 8 amino acids in the case of IGF II $[4,5]$. In contrast to insulin, in the secreted and circulating IGF I and IGF II, the C-peptide is conserved and, in addition, the two hormones have an elongation at the
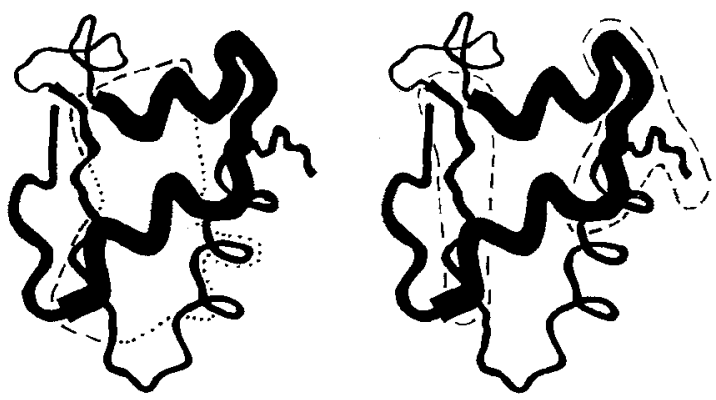

Fig.1. a Proposed receptor binding region and $\mathbf{b}$ antibody regions of insulin projected on the 3-dimensional model of IGF I. The antibody binding regions of insulin and of IGF do not appear to overlap at all. There are as yet no insulin antibodics crossreacting with IGF and vice versa. IGF antibodies recognize the C-loops and their extensions towards the A- and B-domains [7] 
Table 1. Some differences between IGF I and IGF II

\begin{tabular}{|c|c|c|c|}
\hline & \multicolumn{2}{|l|}{ IGF I } & IGF II \\
\hline Structure & \multicolumn{3}{|c|}{$\begin{array}{l}\text { Major amino-acid sequence differences in the } \\
\text { C- and D-domain }\end{array}$} \\
\hline \multicolumn{4}{|l|}{$\begin{array}{l}\text { Receptor affinity } \\
\text { Tyne I }\end{array}$} \\
\hline $\begin{array}{l}\text { Mammalian cells } \\
\text { Chick embryo cell }\end{array}$ & $\begin{array}{l}++++ \\
s++++\end{array}$ & & $\begin{array}{l}+++ \\
+++\end{array}$ \\
\hline \multicolumn{4}{|l|}{ Receptor affinity } \\
\hline Mammalian cells & ++ & & ++++ \\
\hline Serum levels & $200 \mathrm{ng} / \mathrm{ml}$ & & $600 \mathrm{ng} / \mathrm{ml}$ \\
\hline GH dependence & ++++ & & $+(+)$ \\
\hline $\begin{array}{l}\text { Physiological } \\
\text { role }\end{array}$ & $\begin{array}{l}\text { Connective } \\
\text { tissue } \\
\text { growth }\end{array}$ & Differentiation & $\begin{array}{l}\text { Repair } \\
\text { mechanisms }\end{array}$ \\
\hline $\begin{array}{l}\text { Other physio- } \\
\text { logical effects }\end{array}$ & & $\begin{array}{l}\text { Differentiation } \\
\text { of other cells? }\end{array}$ & $\begin{array}{l}\text { Additional } \\
\text { role in CNS? } \\
{[58,59]}\end{array}$ \\
\hline
\end{tabular}

$++++=$ strong; $+=$ weak; $\mathrm{CNS}=$ central nervous system

Table 2. Major differences between IGF I and insulin

\begin{tabular}{|c|c|c|}
\hline & Insulin & IGF I \\
\hline Origin & Islet $B$ cells & $\begin{array}{l}\text { Liver (other cells } \\
\text { in vitro) }\end{array}$ \\
\hline Structure & $\begin{array}{l}2 \text { chains, C-peptide } \\
\text { cleaved off }\end{array}$ & $\begin{array}{l}1 \text { chain, C-peptide } \\
\text { conserved }\end{array}$ \\
\hline Half-life & $10 \mathrm{~min}$ & $16 \mathrm{~h}$ \\
\hline $\begin{array}{l}\text { Daily production } \\
\text { rate }\end{array}$ & $2 \mathrm{mg}$ & $0.5-2 \mathrm{mg}$ \\
\hline Binding protein & None & Two forms \\
\hline Plasma level & $0.5-5 \mathrm{ng} / \mathrm{ml}$ & $200 \mathrm{ng} / \mathrm{ml}$ \\
\hline Secretion & $\begin{array}{l}\text { Emeiocytosis, } \\
\text { pulsatile secretion }\end{array}$ & Constant slow release \\
\hline Receptor & Insulin receptor & $\begin{array}{l}\text { IGF receptor } \\
\text { (type I, type II) }\end{array}$ \\
\hline $\begin{array}{l}\text { Physiological } \\
\text { functions }\end{array}$ & $\begin{array}{l}\text { Rapid modulation of } \\
\text { fuel homeostasis and } \\
\text { enzyme synthesis }\end{array}$ & $\begin{array}{l}\text { Slow initiation of } \\
\text { growth processes, } \\
\text { cellular differentiation }\end{array}$ \\
\hline
\end{tabular}

C-terminus of the A-chain consisting of 8 (IGF I) and 6 (IFG II) amino acids. The homology between IGF I and IGF II on the one hand and insulin on the other, is of the order of $45 \%$ in the A- and B-region, whereas there is no resemblance between these two groups of hormones in the C-peptide region [7]. From the point of view of evolution, IGFs and insulin stem from a common precursor molecule which was encoded for by a gene that underwent duplication about 600 million years ago. The subsequent gene duplication which led to diversion into IGFI and IGF II may have taken place about 300 million years ago, i. e. when mammals appeared on earth. In this context it is of interest that the sera of all mammals so far tested exhibit IGF I- and IGF II-like activity in radioimmuno- and/or radioreceptor assays for the human peptides. Whereas the
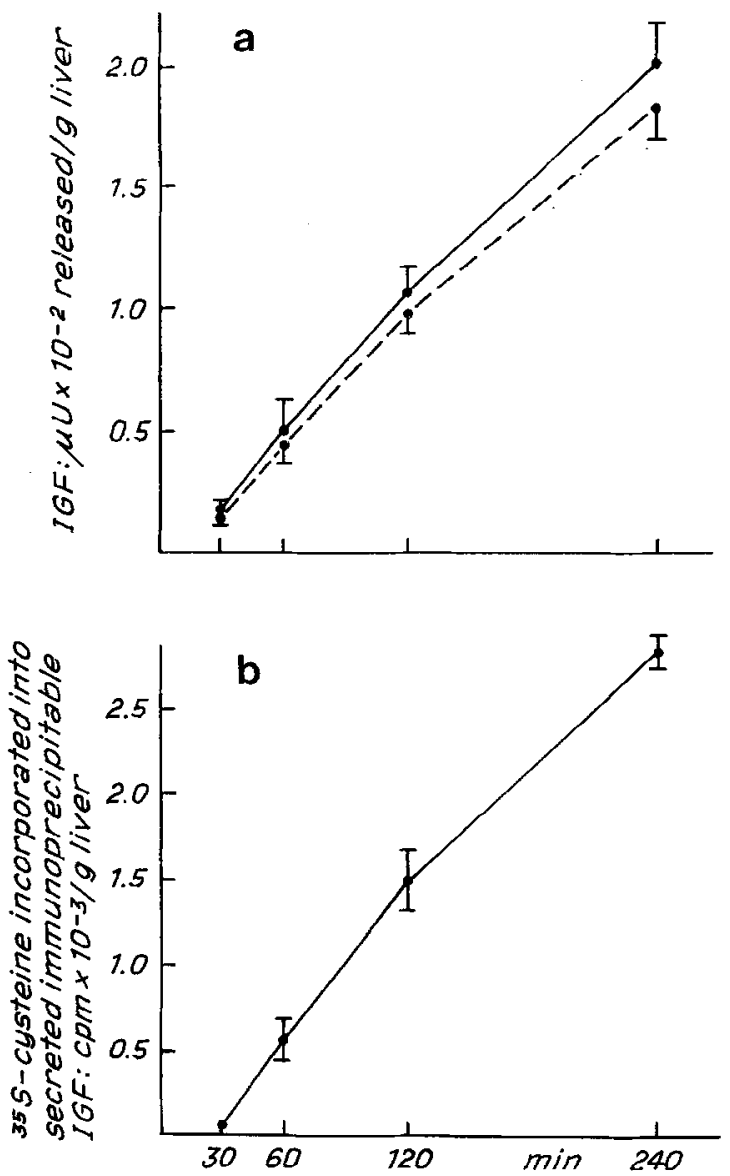

Fig. 2. a Secretion and b synthesis of IGF by isolated normal rat livers $(n=3)$ during recirculating perfusion. Rat IGF release was determined by two assays using the serum binding protein and lipogenesis in isolated fat cells labelled with $\mathrm{U}-{ }^{14} \mathrm{C}$-glucose. The secreted IGF was immunoprecipitated with IGF I-antibodies and ${ }^{35} \mathrm{~S}$-cysteine incorporated in the precipitate was counted. Synthesis and secretion of IGF are linear and parallel processes and the specific radioactivity of the IGF molecule forms a plateau after only $60 \mathrm{~min}$ of recirculation [24]

IGF I molecule of most species tested crossreacts with antibodies raised against human IGF I, the same does not hold true for IGF II. Polyclonal antibodies against IGF I and IGF II mainly appear to recognize the C-region and its close environment in the respective molecule. It appears, therefore, that the C-peptide region was well conserved in the case of IGF I and lesser so in the case of IGF II. Bovine IGF is identical to human IGF (Professor Humbel, personal communication). There appear to exist two slightly different genes encoding for IGF II [17]; Professor Humbel, personal communication]. Whether each chromosome contains two different IGF II genes or whether each individual has one out of two possible genes encoding for two slightly different IGF II molecules is not known. However, it is possible to determine IGF II with a receptor assay using plasma membranes of rat liver cells which recognize IGF II almost exclusively and which crossreact with the respective IGF II-like molecules of many species [18, 19 ; I.Zangger, unpublished observations]. 
Table 3. Comparative biological potency of IGF I and insulin

\begin{tabular}{|c|c|c|c|c|}
\hline & \multicolumn{3}{|c|}{$\begin{array}{l}\text { Concentration range } \\
(\mathrm{ng} / \mathrm{ml})\end{array}$} & \multirow{2}{*}{$\frac{\text { Potency ratic }}{\text { IGF/Insulin }}$} \\
\hline & IGF & & Insulin & \\
\hline \multicolumn{5}{|c|}{$\begin{array}{l}\text { Effects on DNA } \\
\text { synthesis and/or } \\
\text { replication and/or } \\
\text { differentiation of cells in } \\
\text { culture }\end{array}$} \\
\hline $\begin{array}{l}\text { Clavaria cells } \\
\text { Rat }\end{array}$ & 5 & -200 & $200-5000$ & $25-50$ \\
\hline $\begin{array}{l}\text { Cartilage } \\
\text { Chick embryo } \\
\text { Rat costal }\end{array}$ & $\begin{array}{l}5 \\
0.5\end{array}$ & $\begin{array}{l}-200 \\
-\quad 50\end{array}$ & $\begin{array}{r}500-5000 \\
10-1000\end{array}$ & $\begin{array}{l}25-100 \\
20\end{array}$ \\
\hline $\begin{array}{l}\text { Myoblasts } \\
\text { Chick embryo }\end{array}$ & 5 & -200 & $5-200(?)$ & $1-2$ \\
\hline $\begin{array}{l}\text { Liver cells } \\
\text { Chick embryo }\end{array}$ & 1 & -100 & $1-100$ & 1 \\
\hline $\begin{array}{l}\text { Erythroid pre- } \\
\text { cursor cells } \\
\text { Mouse }\end{array}$ & 5 & -500 & no effect & - \\
\hline
\end{tabular}

Insulin-like effects

(glucose uptake,

glycogen formation,

inhibition of lipolysis,

etc.)

Fibroblasts

Chick embryo

$0.25-\quad 25 \quad 25 \quad-2500 \quad 100$

Calvaria cells

rat

$5-200$

$200-5000$

$25-50$

Heart muscle

Rat

4- 400

$1-100$

$1 / 4$

Striated muscle

Mouse

50-1000

$5-100$

$1 / 10-1 / 20$

Adipocytes

Rat

10- 200

$0.2-$

$1 / 50-1 / 100$

Liver cells Chick embryo

$1-100$

$0.1-\quad 10 \quad 1 / 10-1 / 100$

These data ranges stem from $[10,11,19,32,38,39,40,41,43,44,45$, 46]. They must be considered as approximate ranges rather than accurate "true" figures. One must also keep in mind that cultured cells are often more sensitive to hormones than freshly removed tissues containing the same cells and that the incubation and culture conditions considerably influence the sensitivity to hormones. Species differences must also be taken into account. Chick cells are particularly sensitive to IGF

\section{Plasma membrane receptors}

Two entirely different plasma membrane receptors of the IGFs have been identified. The major receptor which has been termed type I receptor resembles the insulin receptor in every respect [20]. The type I IGF receptor contains a monomer subunit of $130 \mathrm{k}$ daltons which is linked by disulphide bonds to another identical subunit [18] and to other membrane proteins to form complexes of a molecular weight of $300 \mathrm{k}$ daltons. The type II IGF receptor contains a $260 \mathrm{k}$ dalton protein un- der reducing conditions which has a lower apparent molecular weight before reduction $(220 \mathrm{k})$ suggesting that it contains intramolecular disulphide bonds and is not linked by disulfide bridges to other membrane proteins [20]. The type I receptor has a two to fivefold greater affinity for IGF I than for IGF II in most mammalian cells and the same affinity for both IGFs in chick cells. Insulin is recognized by the type I but not by the type II receptor. The type II IGF receptor which may be a nonfunctional receptor, prefers IGF II and MSA over IGF I and there is no cross-reaction with insulin [20]. The type I IGF receptor is a tyrosine kinase and phosphorylates itself after binding IGF [21]. The function of the type II receptor is as yet unknown.

The similarity between the insulin receptor and the type I IGF receptor suggests that with diversion of the precursor molecule of insulin and the IGFs there was a concomitant duplication of the genes responsible for the synthesis of their receptors.

\section{Synthesis and processing of IGF in comparison with insulin}

The synthesis of insulin in the B cell is a complex and highly specialized process $[22,23]$. Pre-proinsulin is processed to proinsulin and the C-peptide is subsequently cleaved off by a highly specialized enzyme system. Both, insulin and C-peptide are packaged in granules from where they are secreted into the interstitial space and thence into the blood by an active secretory mechanism, i.e. emeiocytosis, also called exocytosis. The enzymatic equipment of the $\mathrm{B}$ cell is highly specialized so that insulin biosynthesis and secretion cannot occur in any other cells. This is also reflected in the fact that there are no observations of extrapancreatic tumours with paraneoblastic hyperinsulinism.

Much less is known about the synthesis and secretion of insulin-like growth factors. MSA, the rat homologue of human IGF II, is secreted by strains of Buffalo rat liver cells where the process of synthesis and secretion can be studied. In the intact perfused liver, synthesis and secretion of rat IGF was studied by Schwander et al. [24] in comparison with that of albumin. Similar data were published by Mayer and Schalch [25]. It was found that the secretion of IGF is a continuous process and that incorporation of ${ }^{35} \mathrm{~S}$-cysteine into the secreted hormone reaches a steady state within $1 \mathrm{~h}$ after addition of the labelled amino-acid (Fig. 2). In all these respects, the secretory process of IGF closely resembles that of albumin. Although the existence of prepro- and a proIGF has been proven [13,14], it appears that the processing of these molecules is much less complex than that of insulin. The explanations for this difference are numerous. One of the major reasons may be that the Cpeptide in the IGF molecule is conserved rather than being cut out as is the case for the proinsulin to insulin conversion.

There appears to exist another important consequence of the relatively simple manner of processing 

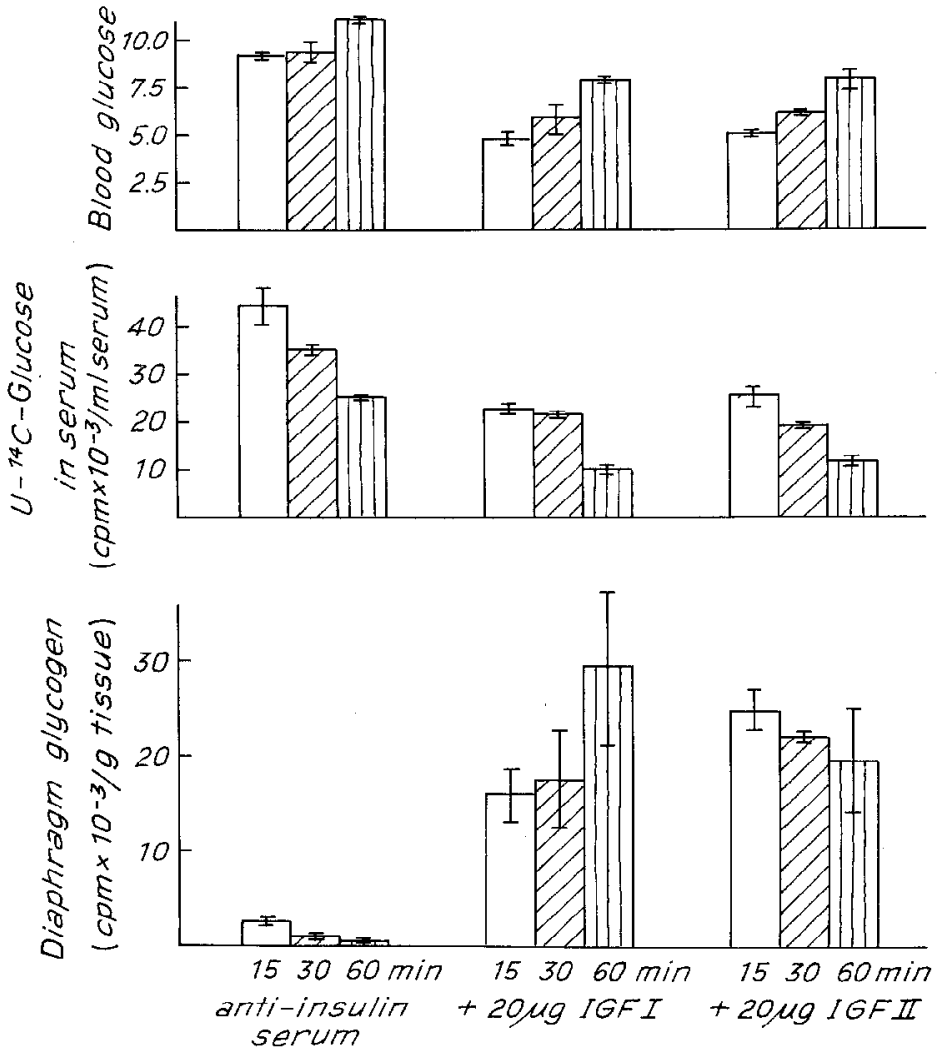

the IGF precursor molecule. There is not much doubt that IGF I is a hormone that obeys the laws of classical endocrinology. The major but not the only site of production is the liver. However, conditioned medium of a variety of cells in culture appears to contain IGF which presumably was secreted by the same cells [26-28]. Besides being a classical hormone, IGF may also have paracrine and/or autocrine activity. Insulin may also have paracrine functions, however, sharply restricted to endocrine pancreatic cells.

\section{IGF binding proteins}

Another important difference between IGF and insulin is that there exist specific carrier proteins of IGF in serum whereas no binding to any serum protein is known in the case of insulin [29-31]. When the gene duplication occurred and the functions of insulin and IGFs separated, nature had to invent a mechanism whereby the insulin-like effects of IGF could be tempered; this was achieved by the synthesis of binding proteins which originate (but not exclusively so) from the liver and bind IGF in such a way that the hormone no longer binds to the insulin receptor and to its own receptor [32]. IGF circulates in blood bound to two carrier proteins, one with a molecular weight of around 50000-60000 and a second, more important one, with a molecular weight of 200000 [33]. These binding proteins are highly specific and only IGFs compete for binding. When cartilage is incubated in serum, IGF affects the tissue in proportion
Fig. 3. IGF I and IGF II were injected intravenously into hypophysectomised rats in doses of $20 \mu \mathrm{g}$ together with anti-insulin serum (neutralizing capacity $100 \mathrm{mU}$ ) and $1 \mu \mathrm{Ci}$ of $\mathrm{U}$ ${ }^{11} \mathrm{C}$-glucose. The rats were killed after $15(\square, 30(\square)$ and 60 (IIII) $\min (n=2)$ and blood glucose and ${ }^{14} \mathrm{C}$ in serum and in glycogen of the diaphragm were determined. The IGFs led to a rapid fall of the blood glucose despite blocking the effects of insulin with anti-insulin serum. The injected $\mathrm{U}^{14} \mathrm{C}$-glucose disappeared rapidly from the serum under the influence of the IGFs and appeared in the glycogen of the diaphragm. The latter parameter is stimulated to a much greater extent than lipogenesis in adipose tissue by IGFs [32] to its total concentration in serum [34]; this is to be expected if the carrier IGF complex dissociates so that free IGF can cross-react with its receptors. Whether additional factors and mechanisms within the tissue help to dissociate the IGF carrier complex is unknown at the present time.

Since both, IGF and the binding proteins are synthesized and secreted by the liver [24], the prepro-IGF could be identical or similar to IGF bound to some form of the carrier protein. There are several reasons to believe that this is not the case. First of all, the liver of hypophysectomized rats secretes close to normal amounts of binding protein, but almost no IGF [24]. This finding, may also be explained by a different processing of the IGF carrier precursor molecule by the liver of normal and hypophysectomized rats, but such an explanation appears rather unlikely. Secondly, if the proteins were bound to IGF in a covalent manner, as would be expected if the two peptides were synthesized together, a cleavage would have to occur followed by a subsequent re-association in a non-covalent bonding. This complex model appears rather unlikely.

The fact that IGF circulates in serum bound to a binding protein has many consequences. Firstly, IGF has an extremely long half-life of $4 \mathrm{~h}$ in the rat and $16 \mathrm{~h}$ in man [35; H. P. Guler, unpublished observations]. Secondly, there exist no diurnal variations, no peaks, no troughs of the IGF serum concentration. Thirdly, IGF in very small amounts in the dissociated form reaches tissues and cells at all times. In all these respects insulin behaves very differently. 

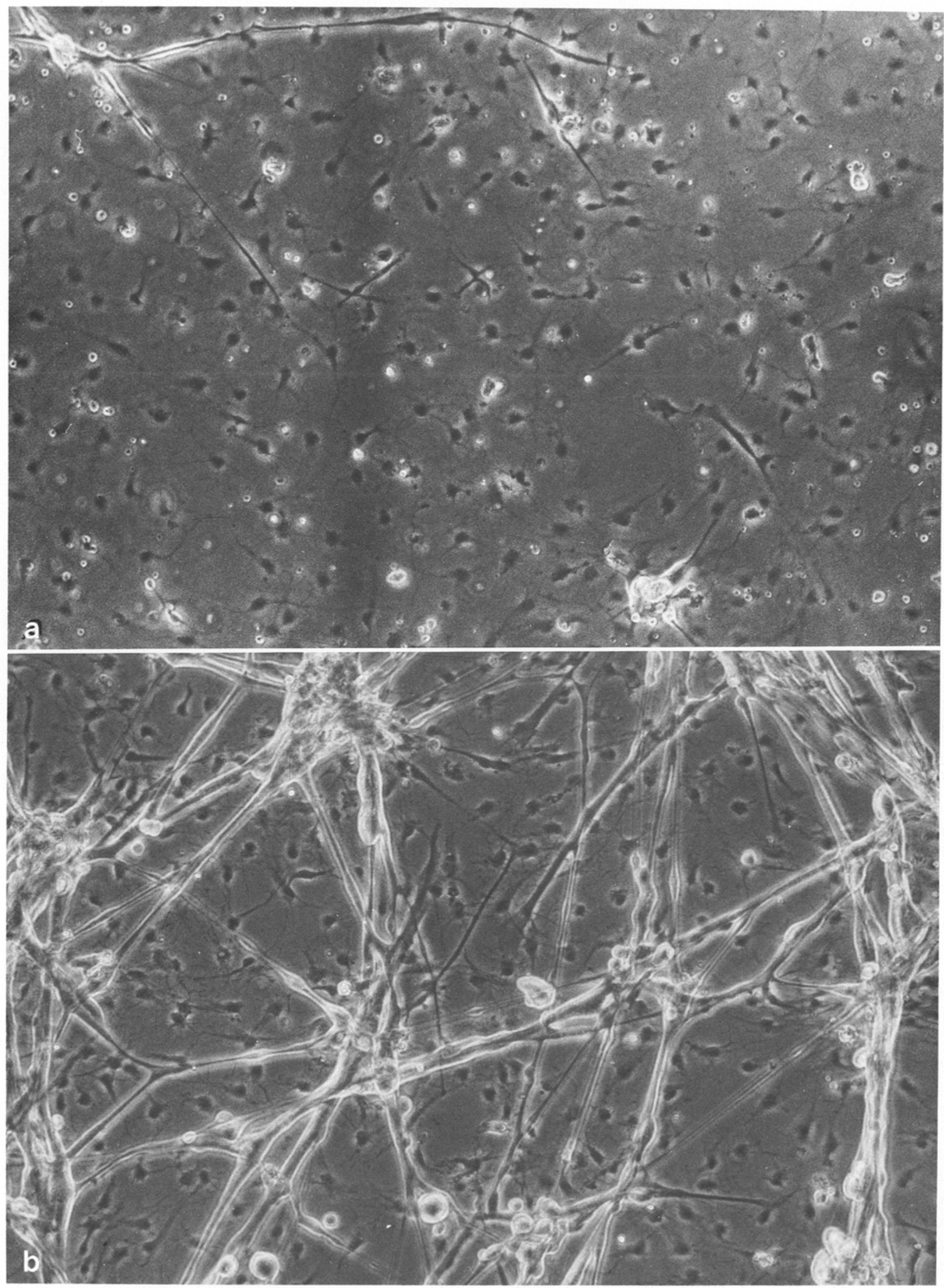

Fig. $4 \mathrm{a}$ and b. Cells from the body walls of 10 -day-old chicken embryos were plated in MEM-Eagle medium at a density of $1.4 \times 10^{6}$ cells per dish (Falcon, $35 \mathrm{~mm}$ diameter). Human serum albumin was present $(65 \mathrm{mg} / 1)$. Phase contrast photomicrographs (magnification: $500 \times$ ) show these cells after 3 days of culture; $\mathbf{a}$ without any additions, $\mathbf{b}$ with addition of IGF I (100 $\mathrm{ng} / \mathrm{ml})$. Myotubes are very prominent in the latter [43] 


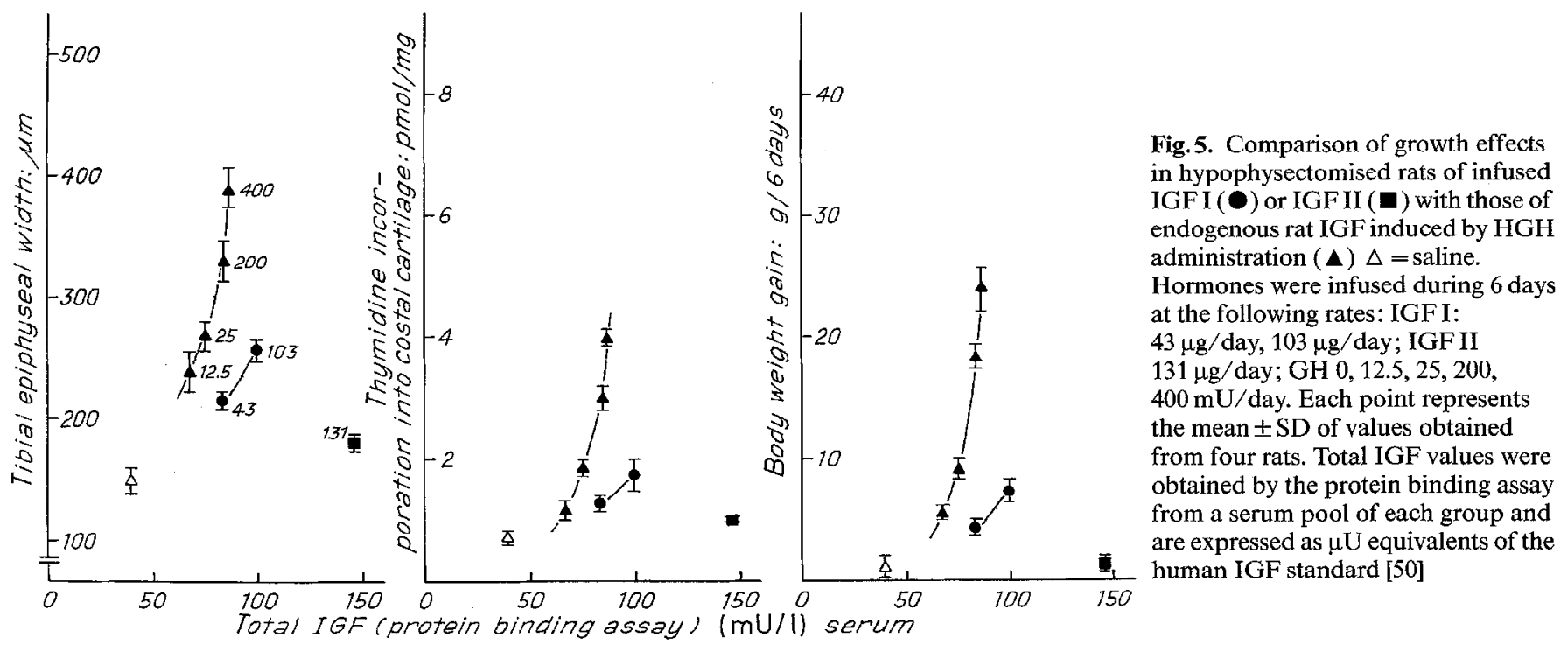

Table 4. Relationship between IGF I, insulin and diabetes mellitus

\begin{tabular}{lll}
\hline Insulin deficiency $\rightarrow$ IGF I $\downarrow$ & $\begin{array}{l}\text { (diabetes, fasting, men, } \\
\text { dog, rat) }\end{array}$ \\
IGF I $\uparrow$ & $\begin{array}{l}\text { (acromegaly) } \\
\text { IGF I } \downarrow\end{array}$ & $\begin{array}{l}\text { High insulin levels } \\
\text { High insulin response }\end{array}$ \\
IGF I $\uparrow$ & $\begin{array}{l}\text { Laron dwarf) } \\
\text { In some diabetic patients with accelerated proliferative } \\
\text { diabetic retinopathy }\end{array}$ \\
IGF I $\uparrow$ & $\begin{array}{l}\text { In acromegalics with diabetes mellitus, no increase in } \\
\text { incidence and severity of retinopathy }\end{array}$ \\
\hline
\end{tabular}

There are many physiological ties between insulin and IGF I. Insulin deficiency is concomitant with considerably decreased IGF I levels which are restored towards normal by adequate insulin substitution. Low IGF I levels in the presence of low human growth hormone (HGH), (pituitary dwarfs) or normal or high HGH levels (pigmies, Laron dwarfs) occur with a "high insulin response". It remains to be established whether the effects on insulin secretion are mediated by IGF I or whether HGH itself is responsible. Normal and/or high HGH levels in pigmies and Laron dwarfs favour a role of IGF. The causal relationship between rapidly progressing proliferative diabetic retinopathy is not clear (from $[34,35,47,48,51,53,54,55]$ )

\section{Biological effects of the IGFs in comparison with those of insulin}

Although the conventional and classical bioassay for IGFs making use of rat epididymal fat pads or rat fat cells is still valuable and in use [36], this tissue is by no means a major target organ of IGFs. The IGFs given intraperitoneally or intrevenously preferentially stimulate the metabolism of striated muscle $[36,37]$ and heart muscle [38]; this was shown many years ago for striated muscle in vivo, for the heart in vitro [38] and later by Poggi et al. for striated muscles in vitro [39]. Results of an intravenous bolus injection of IGF I and IGF II into hypophysectomized rats are shown in Figure 3. Both factors induce a fall of the blood sugar and a stimulation of glucose incorporation into glycogen of the diaphragm. However, the major effects of IGFs are on growth of cells of mesodermal origin [40] and on their differentiation [41]. It has been demonstrated that chondrocytes in culture [42; U. Vetter personal communication], calvaria cells in culture [44], premyoblasts in culture [43] and also erythroid precursor cells [45], not only replicate under the influence of IGFs, but that IGF maintains them in a highly differentiated state (Fig. $4 \mathrm{a}$, b). These effects are shared by insulin. However, insulin is about 50-100 times less potent than IGF in most systems. The constant high levels of IGF in the bound form in serum may, therefore, serve several functions: replacement of dying cells, repair mechanisms, matrix synthesis and perhaps also a constant stabilization of cells keeping them from transforming and dedifferentiating. This latter postulated function is entirely speculative and needs to be investigated experimentally.

\section{Are there disorders due to an IGF excess and IGF deficiency?}

The postulate of Salmon and Daughaday formulated in 1957 [3] that the effects of growth hormone are mediated by the so-called sulphation factors, later called somatomedins, has been proven to be correct. Growth hormone deficiency exists with very low levels of IGF I, growth hormone excess with high levels of IGF I [46]. Under normal circumstances, IGF I levels are regulated mostly by growth hormone. However, this is not true under disease conditions, e.g. malnutrition which leads to IGF I deficiency, despite the fact that concomitant growth hormone levels may be high. This is also not true for diabetes in rats and dogs [47]. IGF I levels drop rapidly to low levels when animals are entirely insulindeficient and they can be restored towards normal by insulin replacement therapy [47]. Under all these circumstances IGF I levels do not reflect the growth hormone status but rather nutrition and the degree of metabolic control by insulin [48]. How these different factors interact to lead to the synthesis and secretion of IGF I by the liver is not known. 
It has been definitively shown that IGF I is capable of stimulating the growth of hypophysectomized rats in the complete absence of growth hormone and without replacement therapy of other hormones such as cortisol, T3 or sex hormones. Osmotic Alza pumps filled with IGF I were implanted subcutaneously into hypophysectomized rats. The rats promptly started to regain weight, the epiphyseal tibial width increased and so did the metabolic activity of cartilage (Fig. 5) [49, 50]. The effects obtained with IGF I could not be distinguished from those obtained with growth hormone in the infusion pumps. These investigations prove that IGF I is the most important mediator by which growth hormone, nutrition and insulin stimulate growth processes. In the hypophysectomized rat, insulin does not stimulate growth because IGFI is absent. In the diabetic animal, on the other hand insulin does stimulate growth because the IGF I levels are normalized. We have shown

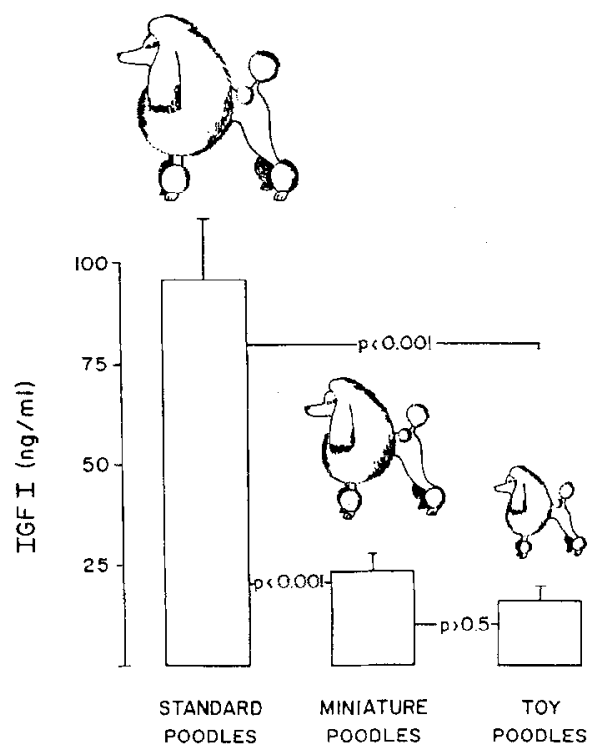

Fig. 6. Mean ( \pm SEM) plasma concentrations of insulin-like growth factor I (IGF I) in 10 standard, 10 miniature and 10 toy poodles and approximate relative body size of each subgroup. Differences were evaluated from significance by employing the Students's t-test [54] in preliminary experiments that the substitution of IGF I to diabetic rats tends to normalize metabolism and growth (E. Muralt, unpublished observations).

There are many other indications that IGF I is the major growth hormone in man and mammals in general. Pygmies are dwarfs who have normal pituitary function but are deficient in IGF I [51]. Laron dwarfs have very low IGF I levels [52], some also have low IGF II levels in the presence of increased growth hormone levels and increased responses of growth hormone to various stimuli. The pygmy trait probably occurs also in other human races and interestingly enough, among other mammals. Eigenmann et al. [53] have shown that the toy poodle, which reaches a final weight of between 2 and $3 \mathrm{~kg}$, has extremely low IGF I levels, which are approximately $10 \%$ of those found in the king poodle (Fig. 6). It appears likely that IGF I levels determine the size of animals within a given species [53, 54].

However, during the development and life of man, IGF I levels do not reflect the actual growth status. Thus, IGF I levels are very low at birth and remain so during the first years of life [55]. Only during puberty do they increase above normal levels and in some way reflect the growth spurt that occurs during this period [55]. During old age IGF I levels may be slighly lower than during the fourth and fifth decade, but these results are statistically not significant. It remains to be elucidated whether the IGFs are unimportant during early childhood or whether IGF I levels do not reflect its efficacy. It is, for instance, conceivable that cells and tissues of young individuals may have better access to bound IGF than cells and tissues of old individuals and that the hormone levels do not reflect hormone turnover and status. This speculation is, as far as we know, not yet undermined by any data.

\section{Conclusions and outlook}

In 1967 my Minkowski lecture dealt with the inhibition of lipolysis. One of the main points was that the inhibition of lipolysis [56] by insulin and certain drugs leads to

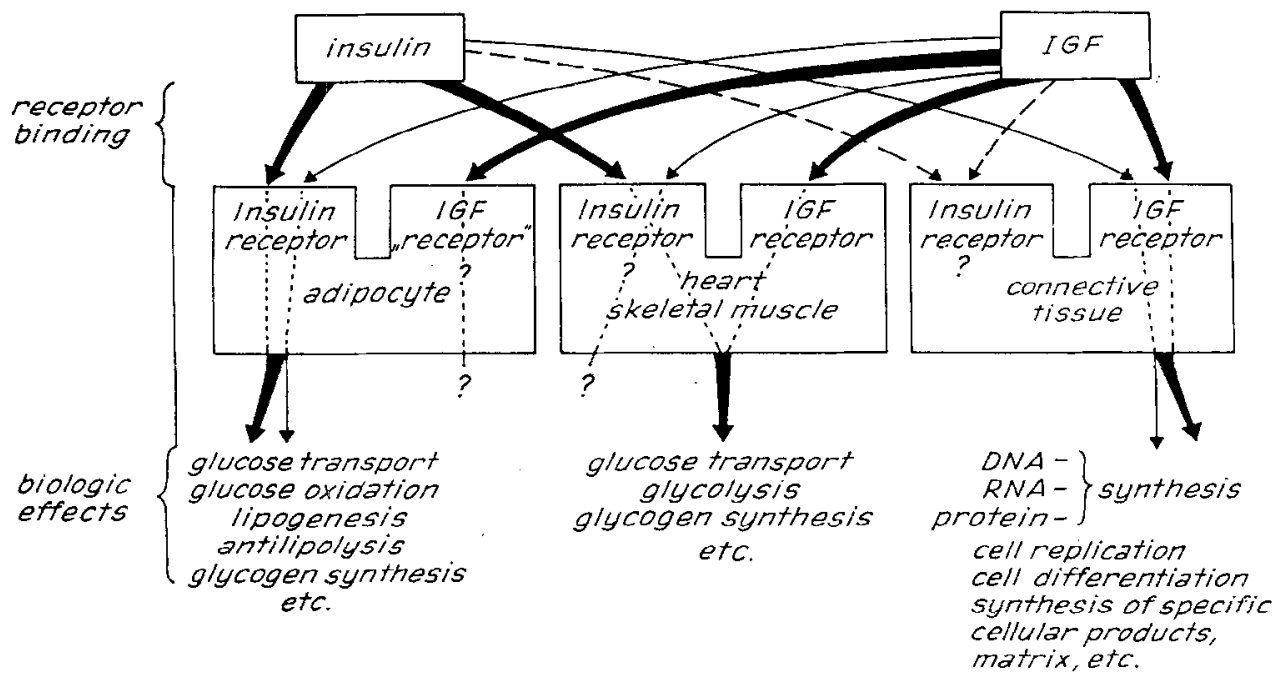

Fig. 7. Complementary anabolic action of insulin and IGF. Insulin is a prerequisite without which growth processes cannot be initiated. IGF appears to have taken over from the common ancestor molecule the regulation of the slow growth porcesses and the stimulation of the differentiation of some mesenchymal cells [26] 
an overshoot of lipolysis once the drug or insulin is not longer present. This work had been carried out in view of earlier studies by Randle [57] who had written his Minkowski lecture on the glucose-fatty acid cycle and demonstrated that insulin is relatively ineffective on glucose metabolism when there is fuel competition by non-esterified fatty acids. We then already knew that there are substances in serum which not only increase glucose metabolism of adipose tissue, but also inhibit lipolysis much in the same way as insulin. At that time, these factors appeared to be of interest as possible inhibitors of lipolysis. In 1978 these factors were identified as insulin-like growth factor I and II and they now have reached an interest far beyond that of the inhibitory effects on lipolysis. Adipose tissue is the least sensitive tissue to insulin-like growth factors, followed by muscle, which is relatively more sensitive and by chondrocytes and osteoblasts which are extremely sensitive and, indeed, much more sensitive to IGF than to insulin. All these cells are of mesenchymal origin and profoundly influenced by insulin and by the insulin-like growth factors. However, the potency ratio between these hormones is greatly in favour of insulin in the case of adipose tissue and in favour of the IGFs in the case of chondrocytes and osteoblasts. Therefore, these two hormones have reached completely different spectra of activity during evolution. Insulin regulates the second to second fluctuations of the major metabolites such as glucose, amino acids, free fatty acids and ketone bodies. The IGFs initiate processes which are responsible for growth and for differentiation. Insulin and the IGFs have become complementary hormones in their anabolic actions on the major tissues (Fig. 7). The IGFs are potentially interesting compounds perhaps even with therapeutic implications in all those situations in which insulin is not able to restore anabolism because the damage concerns mostly cartilage and bone which are only marginally influenced by physiological concentrations of insulin. Soon, biosynthetic IGF I will become available in sufficient amounts to test the hypothesis that IGF I may have therapeutic advantages over insulin, because it stimulates muscle preferentially over adipose tissue. There are reasons to believe that the two hormones which complement each other so well under physiologic conditions may also do so under pathophysiological conditions such as polytraumatism, wound and fracture healing, and, why not, diabetes. My Minkowski lecture in 1967 [56] ended with the sentence "We are now further purifying this molecule and hope to get enough material to test it in man for favourable antidiabetic properties". Now, 18 years later, we finally can test these speculations.

Acknowledgements. These studies were supported by the Swiss National Science Foundation for Scientific Research (Grant nos. 3.167-0.81 and 3.380-0.78).

\section{References}

1. Banting FB, Best $\mathrm{CH}$ (1922) The internal secretion of the pancreas. J Lab Clin Med 7: 251

2. Sanger F, Thompson EOP, Kital R (1955) The amide groups of insulin. Biochem J 59:509

3. Salmon WD jr, Daughaday WH (1957) A hormonally controlled serum factor which stimulates sulfate incorporation by cartilage in vitro. J Lab Clin Med 49: 825-836

4. Rinderknecht $\mathrm{E}$, Humbel RE (1978) The amino acid sequence of human insulin-like growth factor I and its structural homology with proinsulin. J Biol Chem 253: 2769-2776

5. Rinderknecht E, Humbel RE (1978) Primary structure of human insulin-like growth factor II. FEBS Lett 89: 283-286

6. Klapper DG, Svoboda ME, van Wyk JJ (1983) Sequence analysis of somatomedin $\mathrm{C}$ : Confirmation of identity with insulin-like growth factor I. Endocrinology 112: 2215-17

7. Engberg G, Carlquist M, Jörnball H, Hall K (1984) The characterization of somatomedin A, isolated by microcomputer-controlled chromatography, reveals an apparent identity to insulin-like growth factor I. Europ J Biochem 143: 117-124

8. Froesch ER (1983) From NSILA to IGF: A look back on the major advances and breakthroughs. In: Insulin-like growth factors/ somatomedins. Spencer M (ed) Walter de Gruyter, New York, pp 13-29

9. Blundell TL, Bedarkar S, Rinderknecht E, Humbel RE (1978) Insulin-like growth factors: A model for tertiary structure accounting for immunoreactivity and receptor binding. Proc Natl Acad Sci USA 75: $180-184$

10. Zapf J, Schoenle E, Froesch ER (1978) Insulin-like growth factors I and II: Some biological actions and receptor binding characteristics of two purified constituents of nonsuppressible insulinlike activity of human serum. Eur J Biochem 87: 285-296

11. Rechler MM, Zapf J, Nissley SP, Froesch ER, Moses AC, Podskalny JM, Schilling EE, Humbel RE (1980) Interactions of insulin-like growth factors I and II and multiplication-stimulating activity with receptors and serum carrier proteins. Endocrinology 107: 1451-1459

12. Brissenden JE, Ullrich A, Francke U (1984) Human chromosomal mapping of genes for insulin-like growth factors I and II and epidermal growth factor. Nature 310:781-784

13. Tricoli JV, Rall LB, Scott J, Gell GI, Shows TB (1984) Localization of insulin-like growth factor genes to human chromosomes 11 and 12. Nature 310: 784-786

14. Sakaguchi A, Naylor SL, Shows TB (1983) Human c-Ki-ras 2 proto oncogene on chromosome 12. Science 219:1081-1083

15. O'Brien SJ, Nash GW, Goodwin JL, Lowy DR, Chang EH (1983) Dispersion of the ras family of transforming genes to four different chromosomes in man. Nature 302: 839-842

16. De Martinville B, Giacalone J, Shih C, Weinberg RA, Francke U (1983) Oncogene from human EJ bladder carcinoma is located on the short arm of chromosome 11. Science 219:498-501

17. Janson M, van Schaik FMA, Ricker AT, Bullock B, Woods DE, Gabbay KH, Nussbaum AL, Sussenbach JS, van den Brande JL (1983) Sequence of C-DNA encoding human insulin-like growth factor I precursor. Nature 306: 609-611

18. Widmer U, Zapf J, Froesch ER (1982) Is extrapancreatic tumor hypoglycemia associated with elevated levels of insulin-like growth factor II? J Clin Endocrinol Metab 55: 833-839

19. Zangger I, Zapf J, Froesch ER (1985) Insulin-like growth factor I and II in 13 animal species as determined by three radioligandand two bioassays. Acta Endocrinol (Kbh) (in press)

20. Kasuga M, Van Obberghen E, Nissley SP, Rechler MM (1981) Demonstration of two subtypes of insulin-like growth factor receptors by affinity crosslinking. J Biol Chem 256/11: 5305-5308

21. Van Obberghen E, Rossi B, Kowalski A, Gazzano H, Ponzio G (1983) Receptor mediated phosphorylation of the hepatic insulin receptor: evidence that the $95 \mathrm{~K}$ receptor subunit is its own kinase. Proc Natl Acad Sci USA 80: 949 
22. Howell SL, Tyhurst M (1982) Microtubules, microfilaments and insulin secretion. Diabetologia 22: 301-308

23. Wollheim CB, Sharp GWG .1981) Regulation of insulin release by calcium. Physiol Rev 61: 914-973

24. Schwander J, Hauri C, Zapf J, Froesch ER (1983) Synthesis and secretion of insulin-like growth factor and its binding protein by the perfused rat liver: Dependence on growth hormone status. Endocrinology 113: 297-305

25. Mayer PW, Schalch DS (1983) Somatomedin synthesis by a subclone of Buffalo rat liver cells: Characterization and evidence for immediate secretion of de novo synthesized hormone. Endocrinology 113: 588-595

26. Zapf J, Froesch ER, Humbel RE (1981) The insulin-like growth factors (IGF) of human serum: Chemical and biological characterization and aspects of their possible physiological role. Curr Top Cell Regul 19: 257-309

27. Suzuki F, Kato Y, Hiraki Y, Canalis E, Raisz LG (1983) Action of growth factors on chondrocytes: Discovery of local somatomedins in fetal bovine cartilage. In: Insulin-like growth factors/somatomedins. Spencer M (ed) Walter de Gruyter, New York, pp 431-36

28. Stracke H, Schulz A, Moeller D, Rossol S, Schatz H (1984) Effect of growth hormone on osteoblasts and demonstration of somatomedin-C/IGF I in bone organ culture. Acta Endocrinol (Kbh) 107: $16-24$

29. Zapf J, Waldvogel M, Froesch ER (1975) Binding of nonsuppressible insulin-like activity to human serum: Evidence for a carrier protein. Arch Biochem Biophys 168: 638-645

30. Kaufmann U, Zapf J, Torretti B, Froesch ER (1977) Demonstration of a specific serum carrier protein of nonsuppressible insulinlike activity in vivo. J Clin Endocrinol Metab 44: 160-166

31. Moses AC, Nissley SP, Cohen KL, Rechler MM (1976) Specific binding of a somatomedin-like polypeptide in rat serum depends on growth hormone. Nature 263: 137-140

32. Zapf J, Schoenle E, Waldvogel M, Sand I, Froesch ER (1981) Effect of trypsin treatment of rat adipocytes on biological effects and binding of insulin-like growth factors. Further evidence for the action of insulin-like growth factors through the insulin receptor. Eur J Biochem 113: 605-609

33. Zapf J, Waldvogel M, Froesch ER (1975) Binding of non-suppressible insulin-like activity to human serum: evidence for a carrier protein. Arch Biochem Biophys 168: 638-645

34. Schlumpf U, Heimann R, Zapf J, Froesch ER (1976) Nonsuppressible insulin-like activity and sulfation activity in serum extracts of normal subjects, acromegalics and pituitary dwarfs. Acta Endocrinol (Kbh) 81: 28-42

35. Kaufmann U, Zapf J, Froesch ER (1978) Growth hormone dependence of nonsuppressible insulin-like activity (NSILA) and of NSILA-carrier protein. Acta Endocrinol (Kbh) 87: 716-727

36. Froesch ER, Müller WA, Bürgi H, Waldvogel M, Labhart A (1966) Nonsuppressible insulin-like activity of human serum. II Biological properties of plasma extracts with non-suppressible insulinlike activity. Biochim et Biophys Acta 121:360-374

37. Oelz O, Jakob A, Froesch ER (1970) Nonsuppressible insulin-like activity (NSILA) of human serum. V. Hypoglycemia and preferential metabolic stimulation of muscle by NSILA-S. Eur J Clin Invest $1: 48-53$

38. Meuli C, Froesch ER (1975) Effects of insulin and of NSILA on the perfused rat heart: Glucose uptake, lactate production and efflux of 3-O-methylglucose. Eur J Clin Invest 5:93-99

39. Poggi C, Le Marchand-Brustel Y, Zapf J, Froesch ER, Freychet $P$ (1979) Effects and binding on insulin-like growth factor I (IGF I) in the isolated soleus muscle of lean and obese mice: comparison with insulin. Endocrinology 105: 723-730

40. Morell B, Froesch ER (1973) Fibroblasts as an experimental tool in metabolic and hormone studies. II. Effects of insulin and nonsuppressible insulin-like activity (NSILA-S) on fibroblasts in culture. Eur J Clin Invest 3: 119-123

41. Schmid Ch, Steiner Th, Froesch ER (1984) Insulin-like growth fac- tor I supports differentiation of cultured osteoblast-like cells. Febs Lett 173: 48-52

42. Guenther HL, Guenther HE, Froesch ER, Fleisch H (1982) Effect of insulin-like growth factor on collagen and glycosaminoglycan synthesis by rabbit articular chondrocytes in culture. Experientia 38: 979-980

43. Schmid Ch, Steiner Th, Froesch ER (1983) Preferential enhancement of myoblast differentiation by insulin-like growth factors (IGF I and IGF II) in primary cultures of chicken embryonic cells. FEBS Lett 161: 117-121

44. Schmid C, Steiner Th, Froesch ER (1983) Insulin-like growth factors stimulate synthesis of nucleic acids and glycogen in cultured calvaria cells. Calcif Tissue Int 35: 578-585

45. Kurtz A, Jelkmann W, Bauer Ch (1982) A new candidate for the regulation of erythropoiesis. FEBS Let 149: 105-108

46. Zapf J, Morell B, Walter H, Laron Z, Froesch ER (1980) Serum levels of insulin-like growth factor (IGF) and its carrier protein in various metabolic disorders. Acta Endocrinol (Kbh) 95: 505-517

47. Eigenmann JE, Becker M, Kammermann B, Leeman W, Heimann R, Zapf J, Froesch ER (1977) Decrease of non-suppressible insulin-like activity after pancreatectomy and normalization by insulin therapy. Acta Endocrinol 85: 818-822

48. Eigenmann JE, de Bruijne JJ, Froesch ER (1985) Insulin-like growth factor I and growth hormone in canine starvation. Acta Endocrinol (Kbh) 108: 161-166

49. Schoenle E, Zapf J, Humbel RE, Froesch ER (1982) Insulin-like growth factor I stimulates growth in hypophysectomized rats. Nature 296: 252-253

50. Schoenle E, Zapf J, Hauri Ch, Steiner Th, Froesch ER (1985) Comparison of in vivo effects of insulin-like growth factors I and II and of growth hormone in hypophysectomized rats. Acta Endocrinol (Kbh) 1808: 167-174

51. Merimee TJ, Zapf J, Froesch ER (1981) Dwarfism in the pygmy: An isolated deficiency of insulin-like growth factor I. New Engl J Med 305: 965-968

52. Zapf J, Schmid Ch, Froesch ER(1984) Biological and immunological properties of insulin-like growth factors (IGF) I and II. Clin in Endocrinol Metab 13/1: 3-30

53. Eigenmann JE, Patterson J, Zapf J, Froesch ER (1984) Insulin-like growth factor $I$ in the dog: a study in different dog breeds and in dogs with growth hormone elevation. Acta Endocrinol (Kbh) 105: 294-301

54. Eigenmann JE, Patterson DF, Froesch ER (1984) Body size parallels insulin-like growth factor I levels but not growth hormone secretory capacity. Acta Endocrinol (Kbh) 106: 448-453

55. Zapf J, Walter H, Froesch ER (1981) Radioimmunological determination of insulin-like growth factor I and II in normal subjects and in patients with growth disorders and extrapancreatic tumor hypoglycemia. J Clin Invest 68: 1321-1330

56. Froesch ER (1967) The physiology and pharmacology of adipose tissue lipolysis: its inhibition and implications for the treatment of diabetes. Diabetologia 3: 475-487

57. Randle PJ (1966) Carbohydrate metabolism and lipid storage and breakdown in diabetes. Diabetologia 2: 237-247

58. Sara VR, Hall K (1983) Somatomedin receptors in the human brain throughout life. In: Spencer M (ed) Insulin-like growth factors/somatomedins. Walter de Gruyter, New York, pp 544-548

59. Haselbacher G, Humbel R (1982) Evidence for two species of insulin-like growth factor II (IGF II and "big" IGF II) in human spinal fluid. Endocrinology 110: 1822-1824

Professor E. R. Froesch

Stoffwechsellabor

Medizinische Klinik

Universitätsspital Zürich

Rämistr. 100

CH-8091 Zürich

Switzerland 